[ESSAY]

\title{
Assessment Role of Youth in Financial Inclusion: ASEAN Context
}

\author{
Alexander Michael Tjahjadi \\ Economic Research Institute for ASEAN and East Asia \\ alexandermichaeltj@gmail.com
}

\section{INTRODUCTION}

The ASEAN region has experienced high economic growth since 2000. Over the past ten years, ASEAN economic growth had reached 5 percent, even higher than the East Asia and Pacific region (World Development Indicators 2018) . One of the drivers of economic growth is the increasing number of people entering the financial system. In 2011, only $42 \%$ of the total population own a bank account, but the number increased to $50 \%$ by 2014 , an increase of $8 \%$ in just 3 years (The Global Findex Database, 2014). Despite these percentage, there are still a lot of people who are lacking access to the financial system. Financial inclusion is one of the economic development agendas to reach those who are marginalized (ADB 2008). According to the OECD $(201 \neg \neg 8)$, the open access and activeness of the community in using financial products can be translated as financial inclusion. In the process, financial inclusion can reduce transaction costs and increase community participation including informal groups.

This advantage is considered by some countries to be a breakthrough at this time so that for example the G-20 group of nations makes the High-Level Principles for Digital Financial Inclusion (OECD 2018). These guidelines provide direction so that the provision of financial access targets marginalized groups such as those who have less income, and women. To ensure financial access availability, financial products must also be introduced to youth, rural communities, and those with less education.
In the context of the ASEAN region, all heads of state refer to the Framework on Equitable Economic Development in ASEAN (Rillo 2014) where the promotion of financial literacy has excellent attention. In Indonesia, Bank Indonesia's Tabunganku and People's Business Credit (KUR) programmes show that inclusion can reach the outer islands in Indonesia. These programmes enable people to open a bank account with very few requirements and ease access to credit for micro, small, and medium enterprises (UMKM). In addition to Indonesia, the Philippines shows that government policies and a coherent financial sector will make innovation happen. Mobile banking or financial access using mobile phones and the internet can be realized in the Philippines. The same progress can also be found in most of the ASEAN countries.

One group that is of concern in financial inclusion is the youth, those who will soon enter the workforce and contribute to the economy. However, most youths are facing obstruction in accessing formal financial services in the form of legality, high transaction costs, and negative stereotypes, especially in developing countries (United Nations Capital Development Fund, 2013). Without the access to financial services, the youth will not be able to achieve their fullest potential to contribute to the economy (Billimoria, et al. 2013) In Indonesia, financial education conducted by several institutions such as the Ministry of Finance, Bank Indonesia and the Financial Services Authority targets the youth with the goal that they will have savings ('Tambunan 2017). Within the framework of financial education 
by Bank Indonesia, the 2011 education was focused on students, children, and youth. The educational facilities that were mobilized also varied from brochures, "education mobile", as well as the MoU between several state institutions to create financial inclusion programs.

Although it cannot be simplified quantitatively, to facilitate the explanation in the discussion of this essay, the youth is defined as people between the ages of 15 and 35 years in which age groups that can be called millennials in contemporary times. Additionally, the European Commission defines exclusion as the lack of competence and the lack of development in lifelong learning, on the other hand, inclusion means that youth have an excellent opportunity to have control over their decisions that have an impact on economic, social and cultural opportunities. Within this definition, we will be able to get a better image to the concepts of exclusion and inclusion.

To measure the inclusive dimension of youth in financial inclusion, this essay will provide a quantitative description of how much youth have savings or similar financial products. The specification uses microdata from the World Bank known as Findex in 2014. Data collection is carried out using approximately 1,000 respondents interviewed for each country. In this essay, the countries included in the subject matter are Indonesia, Cambodia, Myanmar, Malaysia, Philippines, Singapore, Thailand, and Vietnam, while Laos and Brunei Darussalam were not included because of the unavailability of data.

\section{DISCUSSION}

This section aims to scrutinize the problems that the youth face in the connectivity of financial inclusion. The problems will be examined using two sides of the economy: the demand side and the supply side. The demand side will be represented by the youth, as the consumer of the financial product, and the supply side will be represented by the banks, as the producer of the financial product. In measuring youth involvement in financial inclusion, this essay analysis the factors of gender, education, and wealth in financial inclusion, using comparative statics and will derive the conclusion from the analyisis. The goal is to be able to investigate the demographic factors that influence youth involvement in financial products.

The inclusive financial rate is defined as indexes 0 through 1 . This index is a continuous number where 0 indicates no financial access in the community, while one means that financial access covers the community as a whole.

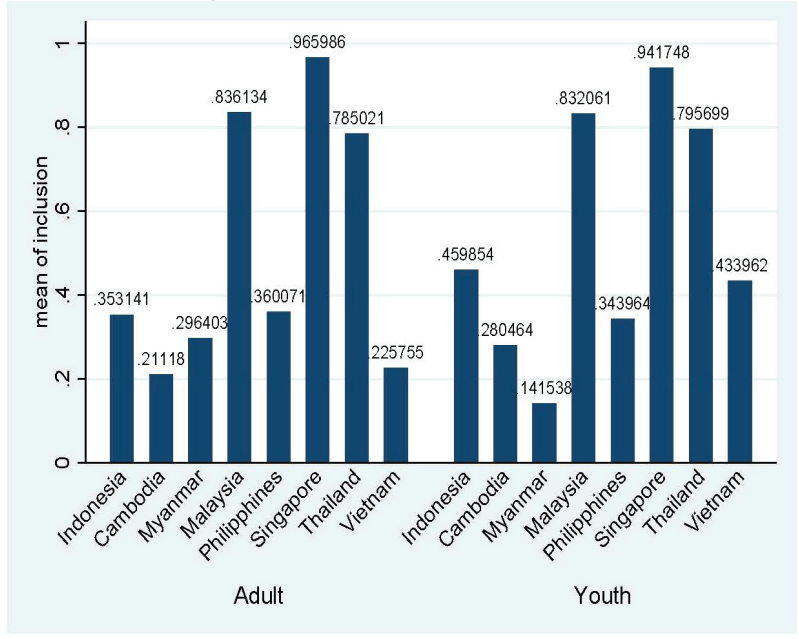

Source: Findex (2014), processed

Graph 1. Financial Inclusion Rate by Youth and Adult Status in ASEAN

Graph 1 shows the level of financial inclusion in the ASEAN region. It can be seen that some countries have a higher level of financial inclusion than other countries. The role of youth is very dominant in several countries such as Indonesia, Cambodia, and Vietnam. In this country, youth have a higher level of inclusiveness than adults. Also, countries that have equal inclusiveness between adults and youth are Malaysia, the Philippines, Singapore, and Thailand. These four countries have even distribution of financial products.

On the other hand, women are still marginalized in financial inclusiveness. Although women play an essential role in the household, the level of female savings ownership is still lower than that of men. In graph 2, it can be explained that on average youth have a higher level of inclusiveness than adults in the ASEAN region. However, adult women have a lower level of inclusiveness than their youth women. This condition shows that women are vulnerable to financial inclusiveness. 


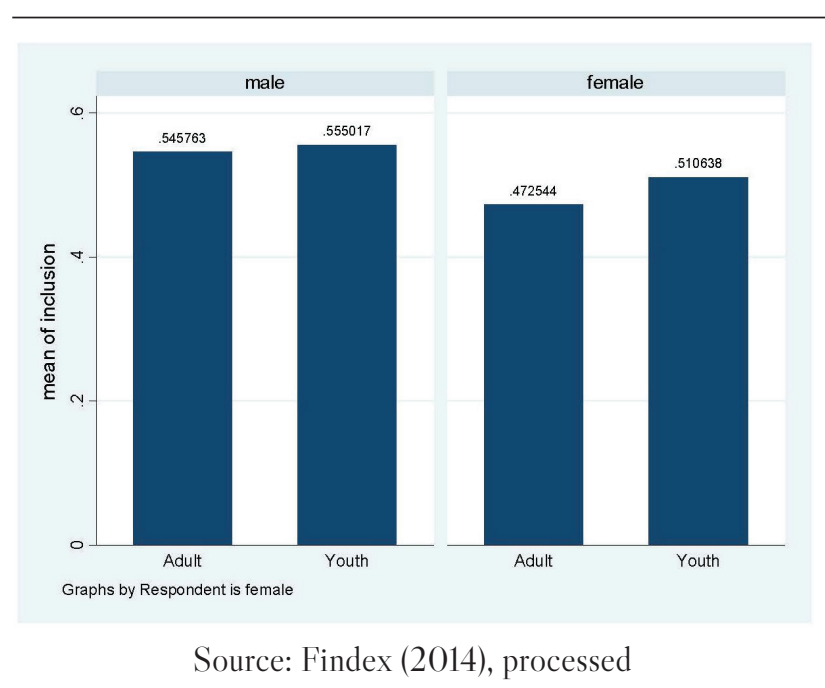

Graph 2. Gender Status on Financial Inclusion Rate in Youth

Regarding education, the average level of financial inclusion will increase as the level of education is completed. That is, the level of education is directly related to financial inclusion. However, what is interesting is that at the level of primary education, the adult population has a higher level of financial inclusion than the youth. This shows that adult residents adapt to their needs. Also, at the secondary education level, the adult population again has greater financial inclusion than youth.

Hunter et al. (2016) show that financial education and financial literacy go hand in hand. In Malaysia, one reason young people don't have savings is lack of knowledge and planning for financial problems. The knowledge in question is about cash flow, credit management, and long-term plan. Findings from randomized evaluations in Indonesia on financial inclusion indicate that financial training will increase the probability of people having savings (CGD 2018).

The need for education at every level of education about finance to be applied in practical terms so that at every age level awareness arises to save. On average, for respondents with higher education, almost all of them have savings. Their perception of the importance of financial services has been formed.

Based on the level of wealth, it can be seen that the higher the concentration of wealth, the more savings that both adults and youth have. Interestingly, the youth group has higher inclusiveness in the poorest, middle-upper, and wealthiest groups. This difference is quite striking especially for the middle class where young people have lower inclusiveness.

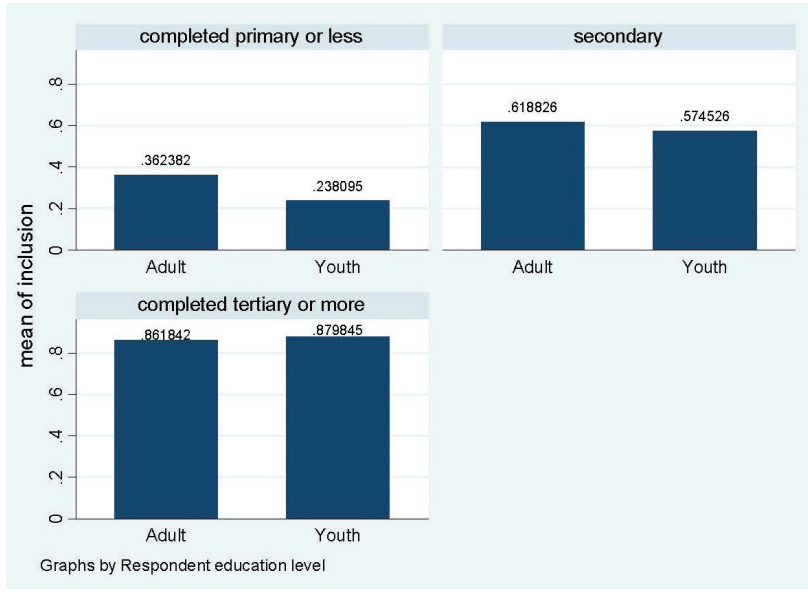

Source: Findex (2014), processed

Graph 3. Educational Status on Financial Inclusion Rate in Youth

From Graph 4 below, we can see that the middle-class youth have lower savings than the adult population. This shows that there is a possibility of poor planning so that they do not have savings. Inequality also occurs especially for young people in the upper class. On average nearly two-thirds have savings and connections with financial products.

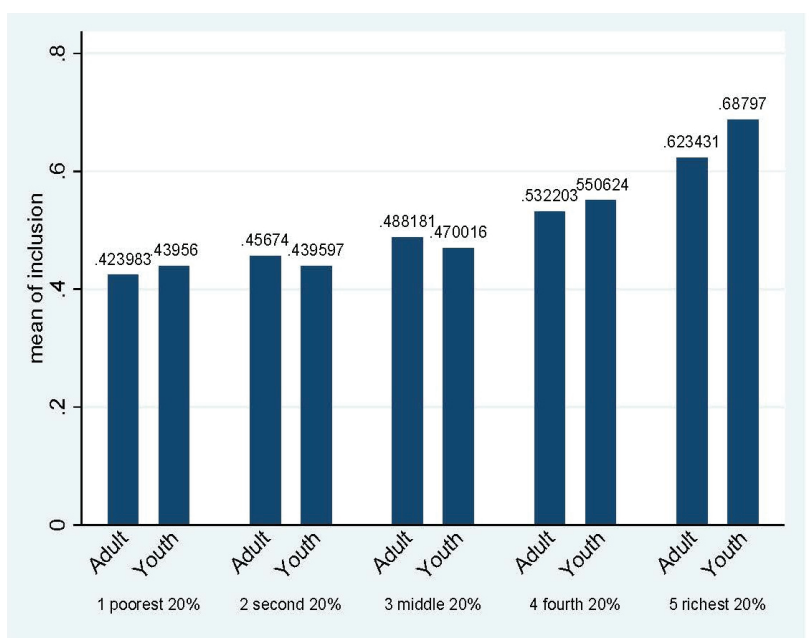

Source: Findex (2014), processed

Graph 4. Wealth Status on Financial Inclusion Rate in Youth

From the supply side, banks have tried to reach the community through various programs. In the Philippines, microinsurance is given to people who are below the poverty line (Hunter, 2016). Indonesia also provides credit assistance through retail agents in rural areas (Tambunan 2017). 
However, the main problems faced by the youth turns out to come from household decision making. The lack of money that can be saved by young people has made them not set aside some parts to save. Also, they have confidence that financial services are not yet needed.

Table 1. The problem faced by Millennial who do not have Bank Account

\begin{tabular}{|l|l|l|}
\hline No & Challenges & $\begin{array}{l}\text { Amount (Percentage } \\
\text { of total millennial) }\end{array}$ \\
\hline 1 & Religious reasons & $133(8 \%)$ \\
\hline 2 & Lack of trust in the bank & $199(13 \%)$ \\
\hline 3 & $\begin{array}{l}\text { Other Family have a bank } \\
\text { account }\end{array}$ & $346(23 \%)$ \\
\hline 4 & $\begin{array}{l}\text { The bank account is too } \\
\text { expensive }\end{array}$ & $439(29 \%)$ \\
\hline 5 & The bank is too far & $474(31 \%)$ \\
\hline 6 & $\begin{array}{l}\text { Requirement document is too } \\
\text { many }\end{array}$ & $477(32 \%)$ \\
\hline 7 & Lack of financial services needs & $639(42 \%)$ \\
\hline 8 & Lack of money to be saved & $1070(70 \%)$ \\
\hline
\end{tabular}

On the other hand, the urgent problem is various regulations and document requirements for opening savings. These two things form an obstacle for young people to be able to connect with financial services. Although the bank is trying to simplify the requirements, there are regulatory differences between banks in the ASEAN region. This is what can inhibit financial inclusiveness, especially for youth.

\section{GONGLUSION}

This article was made with the interest of investigating how demographic factors influence youth involvement in financial products. From the graphical analysis we can infer that demographic factors that are analyzed (gender, education, wealth, income, and regulation) affect financial inclusion to some degree.

Therefore, in solving the problems, regulators, businesses and the public must work together to create financial inclusion. Several efforts or frameworks can be done so that the reach will be more extensive, especially for youth.

The first effort is related to training or financial education. One of the most significant problems of youth is that they do not feel that savings are a necessity for the future. This shows that consumer demand is an obstacle in financial inclusion. The findings of a randomized evaluation in Indonesia show that in addition to financial training for women entrepreneurs providing business benefits, financial training also increases awareness of the importance of financial products (CGD 2018).

Second is the quality of existing regulations. Many regulations make potential customers reluctant to register for financial products. This is especially true for youth, where they do not have savings because of the many requirements, as well as incomplete documents. The right policy is to bring banking closer to the community so that it is more affordable and makes all parties interested in registering for banking products.

The third is the digitalisation of financial services. Youth as part of knowledge society (JRC 2016) cannot be separated from the development of information technology. They are integrated and embedded in systems that are easy to change. With a more digitalized financial system it is expected that household welfare will be improved and small enterprises will be promoted even more (Sapovadia 2017). Furthermore, financial inclusion can be accelerated by providing loans, as well as insurance guarantees for youth (CGAP 2016). The aim is for young people to feel the benefits of financial services and to use them continuously.

The issue here is a general description of youth and financial inclusion in the context of ASE$\mathrm{AN}$, so the problems described here are still general and do not cover all of them. Every issue is specific to each country in the ASEAN region. Understanding the problem is fundamental to achieve financial inclusiveness.

\section{DAFTAR PUSTAKA}

Asian Development Bank (ADB). 2008. Accelerating Financial Inclusion in South-East Asia with Digital Finance. Manila: ADB

Centre for Global Development. 2018. "Unequal Venture". Retrieved 29 September 2018 (https://www.cgdev.org/sites/default/files/unequal-ventures-update-empowering-women-entrepreneurs-revised-august-2018.pdf). 
CGAP. 2016. "Deposit Insurance and Digital Financial Inclusion". Retrieved 29 September 2018 (https://openknowledge.worldbank.org/ bitstream/handle/10986/25707/110632-BRIPUBLIC-ADD-VC-Brief-Deposit-Insuranceand-Digital-Financial-Inclusion.pdf?sequence $=1$ )

Hunter, Shawn, et al. 2016. Financial Inclusion in the Digital Age. Tokyo: Asian Development Bank Institute (ADBI).

Jeero, Billimoria, Pener Jared and Knoote Floor. 2013. "Developing the next generation of economic citizens: financial inclusion and education for children and youth." Enterprise Development and Microfinance Vol. 24

JRC European Commission. 2016. "ICT and Youth at Risk". Retrieved 29 September 2018 (http:/ publications.jrc.ec.europa.eu/repository/bitstream/JRC58427/jrc58427.pdf).

OECD. 2018. "Financial Inclusion and Consumer Empowerment in Southeast Asia”. Retrieved 29 September 2018 (http://www.oecd.org/finance/Financial-inclusion-and-consumer-empowerment-in-Southeast-Asia.pdf).
Rillo, Aladdin, D. 2014. "Overview of Financial Inclusion in Asia" pp. 1-6 in Asian Development Bank Institute (ADBI). Tokyo: ADBI

Tambunan, Tulus. 2017. "Indonesia" pp 169-212 in Yoshino Naoyuki and Peter J. Morgan. Financial Inclusion, Regulation, and Education. Tokyo: ADBI.

United Nations Capital Development Fund. 2013. Financial Inclusion of Youth.

Vrajlal, Sapodia. 2017. Handbook of Blockchain, Digital Finance, and Inclusion. Cambridge: Academic Press.

World Bank. 2014. "The Global Findex Database". Retrieved 29 September 2018 (https://globalfindex.worldbank.org/)

World Development Indicator. 2016. "WDI Database". Retrieved29September2018(https:// data.worldbank.org/indicator/NY.GDP. MKTP.KD.ZG?end=2017\&start=2000) 